\title{
The Effect of Anti-Corruption on the Organizational Climate of Government Departments and the Attitudes of Civil Servants
}

\author{
Jianglin $\mathrm{Ke}$ \\ School of Government \\ Beijing Normal University \\ Beijing, China
}

\author{
Xiaocen Yan* \\ School of Government \\ Beijing Normal University \\ Beijing, China
}

\begin{abstract}
The impact of anti-corruption on the organizational climate of government departments and the attitude of civil servants is still unknown. The empirical study investigated 367 civil servants to explore this problem, and the results show that anti-corruption efforts have significant positive effects on the supportive climate, bureaucratic climate, identity climate and work significance climate of the organizational climate of government departments. It is further found that the more the anti-corruption efforts, the stronger the perception of organizational justice of civil servants in performance appraisal, promotion, salary and other aspects, and the higher the job engagement and job satisfaction. Organizational climate fully mediates the relationship between anti-corruption efforts and the perception of organizational justice, and partly mediates the relationship between anti-corruption efforts and job engagement and job satisfaction. The results suggest that the government should maintain strong anti-corruption efforts to create a good organizational climate and enhance the positive attitudes of civil servants.
\end{abstract}

Keywords-Anti-Corruption; Organizational Climate; Perception of Organizational Justice; Job Engagement; Job Satisfaction

\section{INTRODUCTION}

Anti-corruption is one vital measure to build a clean government. According to the previous study, there were only 30 cadres at or above the deputy office-level investigated and punished in China from 2003 to 2012. But in 2013, the number suddenly increased to 186 , and even reached 380 in 2014 . [1] At present, there are two main streams of academic research on government anti-corruption: implementation strategy and impact effect of anti-corruption. For example, Damania, Fredriksson and Mani (2004) believe that the more perfect the legal system, the fewer opportunities for corruption and the stronger the deterrent of corruption. [2] Fisman \& Gatti (2002) pointed out that increasing economic openness could reduce tariffs and non-tariff barriers to trade, thereby reducing opportunities for corruption. [3] Empirical studies on the impact of anti-corruption are relatively less, and most of them are carried out from the perspective of external society rather than internal organization. Spector (2016) believes that strong anticorruption measures will not only help to establish a good anti-corruption legal system, but also promote the development of social, political, economic and human interests. [4] Yet there are few studies on the impact of anti-corruption on civil servants. [5] This study adapts quantitative empirical research methods to investigate the specific effects of government anticorruption on organizational climate and its dimensions. Based on the research results of organizational climate on the perception of organizational justice, job engagement and job satisfaction in the field of organizational behavior, this study further examines the impact of government anti-corruption efforts on civil servants' attitudes and proves the mediation effect of organizational climate.

\section{LITERATURE AND HYPOTHESIS}

\section{A. Anti-corruption and organizational climate}

People need specific rules to guide themselves and judge and understand things happening around them in social activities. [6] And such rules tend to spread widely among social groups, eventually form the so-called "cultural values." The role of anti-corruption is not simply to punish corrupt officials but to convey fairness to the civil servants and the public. This kind of cultural values advocated by anticorruption promotes the organization's support climate, bureaucratic climate, identity climate, and work significance climate. [7] The study, therefore, proposes the following hypothesis:

Hla: The unit's anti-corruption efforts have a positive effect on the organization's bureaucratic climate, support climate, identity climate, and job significance climate.

\section{B. Anti-corruption and the perception of organizational justice}

Perception of organizational justice refers to the individual's perception of whether members are treated fairly by the organization. [8] Fairness perceptions in performance appraisal, promotion and salary are three important dimensions of the concept. Corruption damages social fairness and justice, distorts legal rules, weakens the institutional foundation, and retards social and economic development. [9] Anticorruption helps to maintain social fairness and justice, and improve the perceptions of organizational justice of members in the organization. Efforts to eliminate corruption not only help to clarify the boundaries between public and private domains but also to resolve conflicts of interest and contribute to transparency, [10] thereby enhance the sense of organizational justice for civil servants. Therefore, the study proposes the following hypothesis: 
justice, job engagement and job satisfaction. Therefore, the study proposes the following hypotheses:

H3a: Organizational climate mediates the relationship between the unit's anti-corruption efforts and the perception of organizational justice of civil servants.

H3b: Organizational climate mediates the relationship between the unit's anti-corruption efforts and job engagement and job satisfaction of civil servants.

\section{METHOD}

about comparing their expected income and actual income. [12] The public sector needs more adequate supervision and more autonomy. [13] Lack of necessary supervision and autonomy are two major factors that make civil servants dissatisfied. Anti-corruption contributes to serious discipline, improves the supervision of civil servants, and maintains and improves the human capital of civil servants. Therefore, the study proposes the following hypotheses:

H1c: The unit's anti-corruption efforts have a positive effect on job engagement of civil servants.

H1d: The unit's anti-corruption efforts have a positive effect on the job satisfaction of civil servants.

\section{Organizational climate and perception of organizational}

justice, job engagement, job satisfaction

In the process of anti-corruption, the enhancement of the bureaucratic climate is a vital achievement, that is, the system construction is continuously improved, and the system implementation is stricter, which is conducive to increasing the procedural fairness, thereby improving civil servants' perception of organizational justice. When individuals are in a highly supportive organizational climate, job satisfaction with the team and job engagement of individuals increase. [14] Anti-corruption improves bureaucratic climate, identity climate and job significance climate and enhances civil servants' job satisfaction and job engagement. Therefore, the study proposes the following hypotheses:

H2a: The organizational climate has a positive effect on the perception of organizational justice of civil servants.

$H 2 b$ : The organizational atmosphere has a positive effect on the job engagement and job satisfaction of civil servants.

\section{E. The Mediation Role of Organizational Climate}

Collective interpretation among the members of the organization determines organizational climate. [15] The socalled sense-making refers to the process of transforming the external environment into a psychological state by taking the information that people understand from the external environment (such as policies or other people's words and deeds) as the starting point of their actions. [16] Organizational climate influences individual attitudes and behavior. Individuals often judge which behavior is justified, expected or feasible based on the organizational climate and the results influence their perception of organizational justice and other impressions of the organization. [17] The vast majority of civil servants are honest and self-disciplined, and will not be directly subject to anti-corruption sanctions. Positive organizational climate has a positive effect on civil servants' perceptions of

\section{A. Sample}

The study collected 655 questionnaires and 367 of them are valid. The effective rate was $72.7 \%$. The samples distributed in Shanxi, Henan, Guangxi, Beijing, Tianjin and other regions, $77.6 \%$ in the eastern region and $22.4 \%$ in the western region. 178 samples are male, accounting for $48.5 \%$, and 189 women, accounting for $51.5 \%$. Working years includes "under 1 year”, "1-3 years”, “3-10 years” and "over 10 years” and each option accounts for $2.5 \%, 7.1 \%, 9.3 \%$, and $81.1 \%$.

\section{B. Measuring}

Anti-corruption. This paper develops the scale of Anticorruption based on the scale developed by Lv Qing (2011), [18] and measures the concept with Likert five-point scale from "completely disagree” to "completely agree" with Cronbach's alpha 0.869 . The scale includes 4 aspects which are anti-corruption education and propaganda, anti-corruption policy formulation, anti-corruption punishment and anticorruption continuous implementation. 11 items were selected based on item analysis and reliability and validity analysis of 131 samples.

Organizational climate. This paper uses the scale of "support climate" and "bureaucratic climate" in the "Organizational Climate Questionnaire" (LSOCQ) developed by Litwin and Stringer (1968) [19] and measures the concept with Likert five-point scale from "completely disagree" to “completely agree” with Cronbach’s alpha 0.863 and 0.857 . This paper uses the scale of "job significance climate" and "identity climate" in the scale developed by Chen and Li (2005) and measures the concept with Likert five-point scale from "completely disagree” to "completely agree” with Cronbach's alpha 0.826 and 0.899 .

Perception of organizational justice. Organizational justice is measured by salary justice, promotion justice and performance appraisal justice. This paper uses the scale developed by Price (1997), [20] and measures the concept with Likert five-point scale from "completely disagree" to “completely agree” with Cronbach’s alpha 0.933, 0.933 and 0.957 respectively.

Job engagement and job satisfaction. This paper uses the scale in UWES and MSQ respectively and measures the concept with Likert five-point scale from "completely disagree" to "completely agree” with Cronbach's alpha 0.920 and 0.909 respectively.

Control variables. Control variables includes gender, marriage, educational background and work experience. Specifically, gender: 0 = female, 1 = male; marriage: 0 = yes 1 
= no; educational background: $1=$ "secondary vocational school and under”, 2 = "bachelor", 3 = "master", 4 = "doctor"; working experience: 1 = " 0 - 1 year", $2=$ " 1 - 3 years", $3=$ = 3 10 years”, $4=$ " $>10$ years”.

\section{Common Method Biases Test}

In order to reduce common variance, the guidance language in the questionnaires instructs that the survey is anonymous and there are no wrong answers. Meanwhile, the research uses the Harman single factor test to verify the extent of homologous error of each research variable. The results suggested that all the factors together explained $38.71 \%$ of the total variance, and Factor 1 explained $15.52 \%$. There was no single factor explaining most of the variance, indicating common method biases of the study is not serious.

\section{RESUltS ANALYSIS}

\section{A. Descriptive Statistics and Correlation Analysis of Variables}

Table 1 shows the results of mean value, standard deviation and Pearson correlation coefficient. There are no abnormal results of mean value and standard deviation. The results show that anti-corruption plays a significant role in promoting organizational climate $(\mathrm{r}=.556, \mathrm{P}<.001)$, perceptions of organizational justice $(r=.500, P<.001)$, job engagement $(r$ $=.529, \mathrm{P}<.001)$ and job satisfaction $(\mathrm{r}=.531, \mathrm{P}<.001)$ of civil servants. Meanwhile perception of organizational justice has a significant positive effect on job engagement $(\mathrm{r}=.629, \mathrm{P}<.001)$ and job satisfaction $(\mathrm{r}=.776, \mathrm{P}<.001)$ of civil servants.

TABLE I. DESCRIPTIVE STATISTICS AND CORRELATION ANALYSIS OF VARIABLES(N=367)

\begin{tabular}{|c|c|c|c|c|c|c|c|c|c|c|c|c|c|}
\hline & $\mathrm{M}$ & SD & 1 & 2 & 3 & 4 & 5 & 6 & 7 & 8 & 9 & 10 & 11 \\
\hline 1 & 4.18 & 0.684 & & & & & & & & & & & \\
\hline 2 & 3.53 & 0.78 & $.556^{* *}$ & & & & & & & & & & \\
\hline 3 & 3.55 & 0.824 & $.385^{* *}$ & $.897^{* *}$ & & & & & & & & & \\
\hline 4 & 3.5 & 0.861 & $.599^{* *}$ & $.894^{* *}$ & $.633^{* *}$ & & & & & & & & \\
\hline 5 & 3.6 & 1 & $.514^{* *}$ & $.854^{* *}$ & $.702^{* *}$ & $.746^{* *}$ & & & & & & & \\
\hline 6 & 3.58 & 1 & $.456^{* *}$ & $.862^{* *}$ & $.787^{* *}$ & $.683^{* *}$ & $.670^{* *}$ & & & & & & \\
\hline 7 & 3.36 & 0.807 & $.500^{* *}$ & $.801^{* *}$ & $.771^{* *}$ & $.645^{* *}$ & $.690^{* *}$ & $.735^{* *}$ & & & & & \\
\hline 8 & 3.45 & 0.85 & $.511^{* *}$ & $.822^{* *}$ & $.766^{* *}$ & $.682^{* *}$ & $.706^{* *}$ & $.768^{* *}$ & $.913^{* *}$ & & & & \\
\hline 9 & 3.43 & 0.866 & $.489^{* *}$ & $.767^{* *}$ & $.699^{* *}$ & $.659^{* *}$ & $.661^{* *}$ & $.695^{* *}$ & $.950^{* *}$ & $.841^{* *}$ & & & \\
\hline 10 & 3.22 & 0.913 & $.386^{* *}$ & $.632^{* *}$ & $.668^{* *}$ & $.452^{* *}$ & $.547^{* *}$ & $.576^{* *}$ & $.902^{* *}$ & $.693^{* *}$ & $.790^{* *}$ & & \\
\hline 11 & 3.87 & 0.845 & $.529^{* *}$ & $.629^{* *}$ & $.470^{* *}$ & $.655^{* *}$ & $.552^{* *}$ & $.518^{* *}$ & $.607^{* *}$ & $.569^{* *}$ & $.611^{* *}$ & $.503^{* *}$ & \\
\hline 12 & 3.58 & 0.76 & $.531^{* *}$ & $.776^{* *}$ & $.725^{* *}$ & $.647^{* *}$ & $.676^{* *}$ & $.705^{* *}$ & $.876^{* *}$ & $.810^{* *}$ & $.829^{* *}$ & $.783^{* *}$ & $.721^{* *}$ \\
\hline
\end{tabular}

(1 Represents anti-corruption efforts, 2 Represents organizational climate, 3 Represents support climate, 4 Represents identity climate, 5 Represents bureaucratic climate, 6 Represents job significance climate, 7 Represents perception of organizational justice, 8 Represents perception of performance appraisal justice, 9 Represents perception of promotion justice, 10 Represents perception of salary justice, 11 Represents job engagement, 12 Represents job satisfaction)

The results show that civil servants perceive strong anticorruption efforts $(\mathrm{M}=4.18)$. The fairness perception of salary is lower than that of performance appraisal and promotion. The correlation coefficient indicates that some hypotheses are preliminarily verified: the anti-corruption efforts have a significant positive correlation with organizational climate, perception of organizational justice, job engagement and job satisfaction; organizational climate has a significant positive correlation with organizational justice and its three subdimensions, job engagement and job satisfaction.

\section{B. The Regression Analysis of the Effect of Anti-corruption on}

Organizational Climate, Perception of Organizational Justice, Job Engagement and Job Satisfaction

The VIF of all models is less than the critical value of 10 , which indicates that there is no serious collinearity problem in the model. The DW value is between 1.960 and 2.040, indicating there is no autocorrelation. By white test, the P-value is greater than the significance level, and there is no Heteroscedasticity in the judgment data. The three tests show that the analysis results of each model are acceptable.
The regression results of Table 2 show that anti-corruption efforts have significant positive effects on support climate $(\beta=$ $0.396, \mathrm{P}<0.01)$, bureaucracy climate $(\beta=0.529, \mathrm{P}<0.01)$, identity climate $(\beta=0.612, \mathrm{P}<0.01)$, job significance climate ( $\beta=0.468, \mathrm{P}<0.01)$, among which the greatest impact is on identity climate, and $\mathrm{H1a}$ is validated. Anti-corruption efforts have a significant positive impact on organizational climate $(\beta=$ $0.570, \mathrm{P}<0.01)$ and the perception of organizational justice $(\beta=$ $0.528, \mathrm{P}<0.01)$. H1b is validated. The anti-corruption efforts have significant positive effects on the fairness perception of performance appraisal $(\beta=0.536, \mathrm{P}<0.01)$, promotion $(\beta=$ $0.511, \mathrm{P}<0.01)$, and salary $(\beta=0.417, \mathrm{P}<0.01)$. Anticorruption efforts have significant positive effects on civil servants' job engagement $(\beta=0.529, \mathrm{P}<0.01)$ and job satisfaction $(\beta=0.551, \mathrm{P}<0.01)$. H1c and H1d are validated. 
TABLE II. THE EFFECT OF ANTI-CORRUPTION EFFORTS(N=367)

\begin{tabular}{|c|c|c|c|c|c|c|c|c|c|c|c|}
\hline & \multirow[t]{2}{*}{ M1 } & M2 & M3 & M4 & M5 & M6 & M7 & M8 & M9 & \multirow[b]{3}{*}{ Job engagement } & \multirow[b]{3}{*}{ Job satisfaction } \\
\hline & & \multicolumn{3}{|c|}{ Organizational climate } & \multicolumn{5}{|c|}{ Perception of organizational justice } & & \\
\hline & 1 & 2 & 3 & 4 & 5 & 6 & 7 & 8 & 9 & & \\
\hline \multicolumn{12}{|l|}{ Control Variables } \\
\hline Gender & 0.032 & 0.003 & 0.077 & 0.023 & 0.055 & -0.035 & 0.015 & -0.066 & -0.044 & 0.054 & 0.007 \\
\hline Working years & -0.057 & -0.045 & -0.054 & -0.055 & -0.046 & -0.132 & -0.109 & -0.109 & -0.147 & 0.007 & -0.089 \\
\hline \multicolumn{12}{|l|}{ Independent variables } \\
\hline anti-corruption efforts & $.570^{* *}$ & $.396^{* *}$ & $.529^{* *}$ & $.612^{* *}$ & $.468^{* *}$ & $.528^{* *}$ & $.536^{* *}$ & $.511^{* *}$ & $.417^{* *}$ & $.529^{* *}$ & $.551^{* *}$ \\
\hline $\mathrm{R}^{2}$ & $.314^{* *}$ & $.150^{* *}$ & $.274^{* *}$ & $.363^{* *}$ & $.214^{* *}$ & $.266^{* *}$ & $.273^{* *}$ & $.253^{* *}$ & $.169^{* *}$ & $.282^{* *}$ & $.289^{* *}$ \\
\hline Adjusted $\mathrm{R}^{2}$ & 0.304 & 0.138 & 0.264 & 0.353 & 0.202 & 0.256 & 0.263 & 0.242 & 0.157 & 0.272 & 0.279 \\
\hline$\triangle \mathrm{R}^{2}$ & $.308^{* *}$ & $.149^{* *}$ & $.266^{* *}$ & $.356^{* *}$ & $.208^{* *}$ & $.265^{* *}$ & $.273^{* *}$ & $.248^{* *}$ & $.165^{* *}$ & $.266^{* *}$ & $.288^{* *}$ \\
\hline $\mathrm{F}$ & 94.773 & 36.885 & 77.207 & 117.79 & 55.859 & 76.181 & 79.298 & 70.035 & 41.981 & 78.203 & 85.535 \\
\hline
\end{tabular}

(1 Represents organizational climate, 2 Represents support climate, 3 Represents bureaucratic climate, 4 Represents identity climate, 5 Represents job significance climate, 6 Represents perception of organizational justice, 7 Represents perception of performance appraisal justice, 8 Represents perception of promotion justice, 9 Represents perception of salary justice)

The results of Table 3 showed that organizational climate had positive effects on the perception of organizational justice ( $\beta$ $=0.807, \mathrm{P}<0.01)$, job engagement $(\beta=0.623, \mathrm{P}<0.01)$, job satisfaction $(\beta=0.778, \mathrm{P}<0.01)$. Organizational climate had

TABLE III. THE EFFECT OF ORGANIZATIONAL CLIMATE(N=367)

\begin{tabular}{|c|c|c|c|c|c|c|}
\hline & M12 & M13 & M14 & M15 & M16 & M17 \\
\hline & \multicolumn{4}{|c|}{ Perception of organizational justice } & \multirow{2}{*}{ Job engagement } & \multirow{2}{*}{ Job satisfaction } \\
\hline & 1 & 2 & 3 & 4 & & \\
\hline \multicolumn{7}{|l|}{ Control Variables } \\
\hline Gender & -0.061 & -0.012 & -0.09 & -0.065 & 0.034 & -0.017 \\
\hline Working years & -0.071 & -0.047 & -0.049 & -0.099 & 0.082 & -0.021 \\
\hline \multicolumn{7}{|c|}{ Independent variables } \\
\hline 5 & $.807^{* *}$ & $.825^{* *}$ & $.772^{* *}$ & $.639^{* *}$ & $.623^{* *}$ & $.778^{* *}$ \\
\hline $\mathrm{R}^{2}$ & $.648^{* *}$ & $.677^{* *}$ & $.598^{* *}$ & $.410^{* *}$ & $.402^{* *}$ & $.603^{* *}$ \\
\hline Adjusted $\mathrm{R}^{2}$ & 0.643 & 0.673 & 0.592 & 0.402 & 0.394 & 0.598 \\
\hline$\triangle \mathrm{R}^{2}$ & $.647^{* *}$ & $.677^{* *}$ & $.593^{* *}$ & $.407^{* *}$ & $.386^{*}$ & $.602^{* *}$ \\
\hline $\mathrm{F}$ & 388.27 & 442.714 & 310.885 & 145.5 & 136.133 & 320.475 \\
\hline
\end{tabular}

(1 Represents perception of organizational justice, 2 Represents perception of performance appraisal justice, 3 Represents perception of promotion justice, 4 Represents perception of salary justice, 5 Represents organizational climate)

Tables 4 and 5 show the effects of organizational climate on the relationships between anti-corruption efforts and perception of organizational justice, job engagement and job satisfaction respectively. The regression results of Table 3 show that the regression coefficient of anti-corruption efforts in model 18 changes from significant to insignificant after adding organizational climate into the model, which indicates that significant positive effects on the fairness perception of performance appraisal $(\beta=0.825, \mathrm{P}<0.01)$, promotion $(\beta=$ $0.772, \mathrm{P}<0.01)$, and salary $(\beta=0.639, \mathrm{P}<0.01)$. $\mathrm{H} 2 \mathrm{a}$ and $\mathrm{H} 2 \mathrm{~b}$ are validated.

TABLE IV. THE EFFECTS OF ORGANIZATIONAL CLIMATE (1) (N=367)

\begin{tabular}{|c|c|c|c|c|c|c|c|c|}
\hline & \multicolumn{2}{|c|}{$\begin{array}{c}\text { Fairness perception of } \\
\text { organizational justice }\end{array}$} & \multicolumn{2}{|c|}{$\begin{array}{c}\text { Fairness perception of } \\
\text { performance appraisal justice }\end{array}$} & \multicolumn{2}{|c|}{$\begin{array}{c}\text { Fairness perception of } \\
\text { promotion justice }\end{array}$} & \multicolumn{2}{|c|}{$\begin{array}{c}\text { Fairness perception of } \\
\text { salary justice }\end{array}$} \\
\hline & M18 & M19 & M20 & M21 & M22 & M23 & M24 & M25 \\
\hline Control Variables & & & & & & & & \\
\hline Gender & -0.035 & -0.059 & 0.015 & -0.01 & -0.066 & -0.088 & -0.044 & -0.063 \\
\hline Working years & -0.132 & -0.09 & -0.109 & -0.065 & -0.109 & -0.068 & -0.147 & -0.113 \\
\hline Independent variables & & & & & & & & \\
\hline $\begin{array}{l}\text { Anti-corruption efforts } \\
\text { Mediator }\end{array}$ & $.528^{* *}$ & 0.099 & $.536^{* *}$ & 0.096 & $.511^{* *}$ & 0.103 & $.417^{* *}$ & 0.077 \\
\hline 1 & & $.752^{* *}$ & & $.773^{* *}$ & & $.716^{* *}$ & & $.598^{* *}$ \\
\hline $\mathrm{R}^{2}$ & $.266^{* *}$ & $.655^{* *}$ & $.273^{* * *}$ & $.683^{* *}$ & $.253^{* *}$ & $.604^{* *}$ & $.169^{* *}$ & $.414^{* *}$ \\
\hline Adjusted $\mathrm{R}^{2}$ & 0.256 & 0.648 & 0.263 & 0.677 & 0.242 & 0.597 & 0.157 & 0.403 \\
\hline$\triangle \mathrm{R}^{2}$ & $.265^{* *}$ & $.389^{* *}$ & $.273^{* *}$ & $.410^{* *}$ & $.248^{* *}$ & $.352^{* *}$ & $.165^{* *}$ & $.245^{* *}$ \\
\hline $\mathrm{F}$ & 76.181 & 236.443 & 79.289 & 271.892 & 70.035 & 186.824 & 41.981 & 87.88 \\
\hline
\end{tabular}


The regression results of Table 5 show that the regression coefficient of anti-corruption efforts decreases after adding organizational climate into model, but it is still significant. This indicates that the organizational climate partly mediates the relationships between anti-corruption efforts and job involvement and job satisfaction. H3b is partially validated.

TABLE V. THE EFFECTS OF ORGANIZATIONAL CLIMATE (2) (N=367)

\begin{tabular}{ccccccc}
\hline & \multicolumn{3}{c}{ Job engagement } & \multicolumn{3}{c}{ Job satisfaction } \\
& M26 & M27 & M28 & M29 & M30 & M31 \\
\hline Control Variables & & & & & & \\
Gender & 0.054 & 0.038 & 0.034 & 0.007 & -0.015 & -0.018 \\
$\begin{array}{c}\text { Working years } \\
\text { Independent variables }\end{array}$ & 0.007 & 0.035 & 0.039 & -0.089 & -0.05 & -0.053 \\
Anti-corruption efforts & $.529^{* *}$ & $.253^{* *}$ & $.191^{* *}$ & $.551^{* *}$ & $.156^{* *}$ & $.202^{* *}$ \\
Mediator & & & & & & \\
1 & & $.485^{* *}$ & & & $.693^{* *}$ & \\
$\mathrm{R}^{2}$ & $.282^{* *}$ & $.444^{* *}$ & $.470^{* *}$ & $.289^{* *}$ & $.619^{* *}$ & $.640^{* *}$ \\
Adjusted $\mathrm{R}^{2}$ & 0.272 & 0.433 & 0.452 & 0.279 & 0.612 & 0.628 \\
$\triangle \mathrm{R}^{2}$ & $.266^{* *}$ & $.162^{* *}$ & $.187^{* *}$ & $.288^{* *}$ & $.330^{* *}$ & $.351^{* *}$ \\
$\mathrm{~F}$ & 78.203 & 61.042 & 18.295 & 85.535 & 182.087 & 50.52 \\
\hline
\end{tabular}

\section{CONCLUSION AND SUGGESTION}

The effect of anti-corruption efforts of government departments on organizational climate. The empirical results show anti-corruption efforts have a positive impact on organizational climate $(\beta=0.396, \mathrm{P}<0.01)$, bureaucratic climate $(\beta=0.529, \mathrm{P}<0.01)$, identity climate $(\beta=0.612, \mathrm{P}<$ $0.01)$ and job significance climate $(\beta=0.468, \mathrm{P}<0.01)$, among which the efforts on identity climate and bureaucratic climate are the strongest. Organizations are not only access to material information, but also an important source of group identity. Being treated fairly strengthens individuals' identity and selfesteem. [21] Anti-corruption strengthens the standardization and fairness of the organization, and improves the identity climate of civil servants. This shows that anti-corruption is very effective for civil servants to improve their job responsibilities and organizational value of identity, perception of organizational support.

The effects of anti-corruption efforts of government departments on the attitude of civil servants. The anti-corruption efforts have positive effects on the perception of organizational justice $(\beta=0.528, \mathrm{P}<0.01)$ of civil servants and the subdimensions of performance appraisal $(\beta=0.536, \mathrm{P}<0.01)$, promotion $(\beta=0.511, \mathrm{P}<0.01)$, salary $(\beta=0.417, \mathrm{P}<0.01)$, job engagement $(\beta=0.529, \mathrm{P}<0.01)$, job satisfaction $(\beta=0.551$, $\mathrm{P}<0.01)$. Anti-corruption reduces the opportunity and behavior undercover operation, reduces the role of "human" factors, and is conducive to fair personnel appointment, performance appraisal and promotion competition. The correlation coefficient between anti-corruption efforts and job engagement reaches 0.529 ( $\mathrm{p}<0.01$ ), which indicates that anti-corruption does not lead to laziness but stimulates individual's work enthusiasm.

The mediating effect of organizational climate. Organizational climate fully mediates the relationship between anti-corruption efforts and the perception of organizational justice, and partly mediates the relationship between anticorruption efforts and job engagement and job satisfaction. Anticorruption, organizational climate and perception of organizational justice are all variables at the organizational level. Job involvement and job satisfaction are attitudes of civil servants at the individual level which are influenced not only by organizational factors, but also by other individual factors.
Organizational climate only partly mediates the relationships, which is understandable. Organizational climate can influence the values and beliefs of individuals in an organization, [22] and can also influence the willingness of individuals. Anticorruption changes organizational climate and therefore changes civil servants' perceptions of organizational justice, job engagement and job satisfaction. Research shows that work resources (such as skills diversity, job importance, feedback, autonomy, etc.) are conducive to promoting individual growth, learning and development, and are decisive factors in job engagement while weakening negative emotions such as burnout and anxiety. [23] Civil servants value the meaning of work, helping others and the role of society. The importance of work is the work characteristic they value most, which can inspire job satisfaction. [24] The importance of work and job feedback are the core working characteristics that determine the level of work engagement of civil servants. The dimension of identity climate and job significance climate emphasizes civil servants' recognition of organizations and job. The empirical results of the relationship between organizational climate and civil servants' attitudes support the above views and explain why organizational climate partly mediates the relationships.

Suggestions for the management of civil servants. First, the government should maintain anti-corruption efforts to create a positive organizational climate and enhance the positive attitudes of civil servants. Anti-corruption can not only enhance the credibility of the government but also improve support climate, bureaucratic climate, identity climate and job significance climate within the organization, therefore enhance the perception of organizational justice, job engagement and job satisfaction of civil servants. Government departments at all levels should fully recognize the importance of anti-corruption, strengthen anti-corruption education and propaganda, anticorruption policy formulation, anti-corruption punishment and anti-corruption continuous implementation so that civil servants "dare not corrupt, cannot corrupt, do not want to corrupt". Secondly, the government should create a positive organizational climate to improve the attitude of civil servants. Organizational climate fully mediates the relationships between anti-corruption efforts and the subdimensions of the perception of organizational justice, including performance appraisal, promotion and salary. It also partly mediates the relationships 
[12] G. R. Ferris, D. D. Frink, D. P. Bhawuk, S. Zhou, and D. C. Gilmore, "Reactions of diverse groups to politics in the workplace," Journal of Management, vol. 22, No. 1, pp. 23-44, 1996.

between anti-corruption efforts and job engagement and job satisfaction. This shows that the organizational climate has an important impact on the improvement of civil servants' attitudes.

\section{REFERENCES}

[1] L. Dang, R. L. Yang, and J. D. Yang, "Anti-corruption and firms' innovations: an explanation from political connections," China Industrial Economy, vol. 07, pp.146-160, 2015. (In Chinese)

[2] R. Damania, P. G. Fredriksson, and M. Mani, "The persistence of corruption and regulatory compliance failures: theory and evidence," Public Choice, vol. 121, no. 3, pp. 363-390, 2004.

[3] R. Fisman, and G. Roberta, "Decentralization and corruption: evidence from U.S. federal transfer programs," Public Choice, vol. 113, no. 1, pp. 25-35, 2002.

[4] B. I. Spector, "The benefits of anti-corruption programming: implications for low to lower-middle-income countries," Crime, Law and Social Change, vol. 65, pp. 423-442, 2016.

[5] P. Baboš, "Corruption experience, perception and anti-corruption trust: different effects in various post-communist states," Romanian Journal of Political Sciences, vol. 1, pp. 107-128, 2015.

[6] Q. Miao, "Essence of anti-corruption and prevention from the source: policies advocated, participating atmosphere and normalization of anticorruption methods," Anti-Corruption and Integrity Culture Studies, vol. 2, pp.1-14, 2011. (In Chinese)

[7] P. Baboš, "Corruption experience, perception and anti-corruption trust: different effects in various post-communist states," Romanian Journal of Political Sciences, vol. 1, pp. 107-128, 2015.

[8] Y. Liu, L. R. Long, and Y. Li. "The influence of organizational justice on organizational effectiveness variables," Management World, vol. 3, pp.126-132, 2003. (In Chinese)

[9] C. Ajay. "The state in a changing world (includes related articles on state's effectiveness in developing countries),” Finance \& Development, vol. 34, No. 3, pp. 17-20, 1997.

[10] Y. Guo, "Six tendencies of corruption and anti-corruption in contemporary China," Chinese Public Administration, vol. 1, pp.60-63, 2013. (In Chinese)

[11] B. W. Schaufeli, and B. Arnold, "Job demands, job resources, and their relationship with burnout and engagement: a multi - sample study," Journal of Organizational Behavior, vol. 25, No. 3, pp. 293-315, 2004.
[13] Banks, S. P. Leading, "Dissenting and Public Relations. In S. P. Banks (Ed.), Dissent and Failure of Leadership; Dissent and Failure of Leadership (pp. 97-118, Chapter x, 239 Pages)” Edward Elgar Publishing, Northampton, MA, 2008.

[14] M. Bennett, and A. Bell, "Leadership and talent in Asia. Singapore: John Wiley and Sons (Asia),” Pte Ltd, 2004.

[15] Schneider, B. 'Work Climates: An Interactionist Perspective', in N. W. Feimer and E. S. Geller (eds.), Environmental Psychology: Quality and Perspectives (Praeger, New York), (1983). pp. 106-128.

[16] M. Roderick and E. Weick. "Making sense of the organization," Administrative Science Quarterly, vol. 47, No. 4, pp. 748-752, 2002.

[17] R. Salancik, and J. Pfeffer, “A social information processing approach to job attitudes and task design,” Administrative Science Quarterly: ASQ Dedicated to Advancing the Understanding of Administration through Empirical Investigation and Theoretical Analysis, vol. 23, No. 2, pp. 224253, 1978.

[18] Q. Lv, "Research on the Index System of Anti-corruption Situation Assessment,” Theoretical Investigation, vol. 04, pp.146-148, 2011. (In Chinese)

[19] G. H. Litwin, and R. A. Stringer, Jr. "Motivation and organizational climate,” Oxford, England: Harvard U., Graduate School of Business, 1968.

[20] J. Price, "Handbook of organizational measurement," International Journal of Manpower, vol. 18, No. 4-6, pp. 303-558, 1997.

[21] H. Flint, "The role of organizational justice in multi-source performance appraisal: theory-based applications and directions for research,” Human Resource Management Review, vol. 9, No. 1, pp. 1-20, 1999.

[22] C. J. Collins, and K. G. Smith, "Knowledge exchange and combination: the role of human resource practices in the performance of high technology firms," Academy of Management Journal, vol. 49, No. 3, pp. 544-560, 2006.

[23] W. B. Schaufeli, M. Salanova, V. González-romá, and A. B. Bakker, “The measurement of engagement and burnout: a two sample confirmatory factor analytic approach,” Journal of Happiness Studies, vol. 3, No. 1, pp. 71-92, 2002.

[24] S. A. Frank, and G. B. Lewis, "Government employees: working hard or hardly working?” The American Review of Public Administration, vol. 34, No.1, pp.36-51, 2004. 